\title{
9 Federalism and the COVID-19 crisis
}

\author{
The perspective from Ethiopia
}

Zemelak Ayitenew Ayele

\subsection{Introduction}

The COVID-19 pandemic emerged when Ethiopia was at a political crossroads. The Ethiopian Peoples' Revolutionary Democratic Front (EPRDF), the party that ruled the country in a centralized manner for almost three decades, was forced to undergo a fundamental makeover as a result of the 2015-2018 public protests. The protests saw the rise to power of Abiy Ahmed, the current Prime Minister, who pledged to transform the country to a democratic state. The party underwent not only a change in leadership but also in name (now, it is called Ethiopian Prosperity Party (EPP)), structure (it is no longer a coalition of ethnic-based regional parties), and ideology (it has abandoned revolutionary democracy). The Tigray Peoples Liberation Front (TPLF) - the founder and the nucleus of the EPRDF - has been pushed from the center of political power and is reduced to being a single-region party. The sixth general elections, which were viewed as a litmus test on whether the country was indeed transforming into a democratic state, was scheduled for August 2020. It is in such a national political context that COVID-19 emerged.

This chapter argues that the rise of COVID-19 not only has stalled political reforms in Ethiopia but also exposed certain flaws in the design and operation of the Ethiopian federal system. Severe ongoing disagreements between the EPP and the TPLF erupted into full-scale armed clashes on 4 November 2020, and the conflict is still ongoing at the time of writing. The chapter begins by describing when and how COVID-19 began spreading in Ethiopia and the rate at which it is spreading. It then discusses the Ethiopian federal system, and the role each level of government is expected to play in containing the spread of the virus and whether and how it is discharging its responsibilities in this respect. It concludes with a discussion of how the emergence of COVID-19 is impacting on the Ethiopian federal system (Table 9.1).

Table 9.1 Key Statistics on COVID-19 in Ethiopia as of 10 January 2021

\begin{tabular}{lllll}
\hline $\begin{array}{l}\text { Cumulative } \\
\text { Cases }\end{array}$ & $\begin{array}{l}\text { Cumulative Cases per } \\
100,000 \text { Population }\end{array}$ & $\begin{array}{l}\text { Cumulative } \\
\text { Deaths }\end{array}$ & $\begin{array}{l}\text { Cumulative Deaths per } \\
100,000 \text { Population }\end{array}$ & $\begin{array}{l}\text { Case Fatality } \\
\text { Percentage }\end{array}$ \\
\hline 127,792 & 111.2 & 1,985 & 1.7 & 1.6
\end{tabular}

Source: World Health Organization Weekly epidemiological update - 12 January 2021. Geneva: WHO, 2021. Available from https://www.who.int/publications/m/item/weekly-epidemiological-update

DOI: $10.4324 / 9781003251217-9$ 


\subsection{COVID-19 and the extent of infection}

The first case of COVID-19 in Ethiopia was reported on 13 March 2020, a mere two days after the virus was declared a global pandemic by the World Health Organization (WHO). Since then, the number of those infected has been growing. Although the virus has been spreading at a decreasing rate, it has reached every state of the federation. Addis Ababa, the country's capital and largest city, has seen the highest COVID-19 positivity rates, accounting for two-thirds of the country's total case count.

As of January 2021, there were close to 136,000 confirmed cases of COVID-19 in Ethiopia, and a little over 2,000 people have died due to the virus (Ministry of Health 2021). In a country with a population of 115 million, the number of confirmed cases is indeed relatively low. However, the actual number of infected persons might be much higher, and the low rate of infection and death seems merely a reflection of the limited testing taking place in the country. At the beginning of the pandemic, the country did not even have the technology to conduct tests, and samples were sent to South Africa for assessment. Subsequently, Ethiopia was able to ramp up testing capacity to around 20,000 tests per day and at the time of writing about 1.7 million people had been tested (Ministry of Health 2021). It is thus evident that the testing capacity is far from where it should be despite the federal and state governments' efforts to increase their testing daily capacity since the first confirmed case was reported.

\subsection{Ethiopia's federal system}

\subsubsection{A dual federal system}

In Ethiopia, the federal and state governments both enjoy explicit constitutional recognition (Fiseha 2007). The federation has a bi-cameral Parliament, House of Peoples Representatives, and House of Federation (HoF), even though the latter does not exercise legislative powers (see Ethiopian Constitution 1995). It has also a parliamentary form of government. The federation is composed of ten states ${ }^{1}$ each of which has a state council and parliamentary form of government. The states are organized principally along ethnic lines even though none of the states is ethnically homogenous. Local government, which is composed of rural woredas and cities, enjoys no explicit constitutional recognition (Ayele and Fessha 2012).

\subsubsection{Controlling pandemics in the constitutional division of powers}

The federal government's authority to control pandemic diseases emanates from two constitutional sources. As per Article 51(3) of the 1995 Constitution, the federal government "establishes and implements national standards and basic policy," among others, on public health (see Fiseha and Ayele 2017). This provision therefore gives the federal government policy and legislative responsibility for public health issues, including pandemics. Moreover, a pandemic is a health risk which is often associated with people traveling across national and international borders. As the level of government charged with controlling the country's ports of entry and exit, the federal government is responsible for containing pandemics by determining whether one should be granted entry into the country based on health considerations (Art. 51(18), Ethiopian Constitution 1995). 
Almost all federal agencies seem to have some role to play in containing the virus even though some agencies play a more direct role. The Ministry of Health $(\mathrm{MoH})$ exercises an overall authority on public health related matters (Art. 27, Proclamation 1097). The Ethiopian Food and Drug Control Authority (EFDCA) ${ }^{2}$ and Public Health Institute (PHI) which work under the $\mathrm{MoH}$ have mandates that are linked to fighting pandemics. For instance, the PHI has the mandate to collect, analyze, and disseminate information on, among others, 'epidemic prone diseases' (FDRE 2013). It is also authorized to investigate and verify the outbreak of pandemics and alert concerned organs and supporting state and local government in dealing with pandemics (FDRE 2013). It also exercises regulatory functions in relation to quarantine and communicable diseases (Art. 72(2), Proclamation 1112). The EFDCA is in charge of controlling ports of entry and exits, among others, with the purpose of preventing pandemics. It is empowered to deny individuals entry or exit or subject them to be quarantined in the case of a pandemic (Art. 4(15), Proclamation 661). The Ministry of Peace (MoP), with National Disaster and Risk Management Commission (NDRMC), a federal agency which is answerable to the former, plays certain roles in controlling the COVID-19 outbreak. A National Emergency Coordination Centre (NECC) has been established within the NDRMC 'to coordinate the multi-sector response' to the humanitarian and logistical issues that are linked with containing COVID-19. The NECC, among others, has established quarantine centers and food banks in border areas. Federal and state police and other security agencies play the role of guarding quarantine centers. Moreover, both the federal and state governments are constitutionally empowered to declare a state of emergency (SoE) (Art. 93, Ethiopian Constitution 1995) as a method of containing pandemic diseases, and federal and state police are expected to enforce the SoE.

The states have the power to adopt state-wide policies on social matters and, thus, on matters relating to public health (Art. 52(2)(c), Proclamation 661). The Constitution authorizes them to declare an SoE if doing so is necessary for controlling the spread of endemic diseases (Art. 93(1)(b), Ethiopian Constitution 1995). In practice, a state bureau of health plays a primary role in terms of controlling pandemics. The competence of the local government in the area of public health is not clearly stated in the Constitution nor is it defined in state constitutions and laws even though the latter authorize woredas and cities to prepare and implement their own plan on social and economic matters (Ayele 2014). In any case, in practice, woredas and cities are in charge of providing primary healthcare and establishing health centers (Art. 93(1)(b), Ethiopian Constitution 1995). The local government agency which is responsible for health related matters, and therefore COVID-19, is the woreda/city office of health.

\subsubsection{Federal and state responses to COVID-19}

\subsubsection{Measures to contain the pandemic}

After the first case of COVID-19 was confirmed, the federal and state governments began taking restrictive measures, short of declaring a state of emergency, to contain the spread of the virus. Federal agencies, such as MoH and PHI, began administering temperature checks at airports. The federal government closed all federal offices and asked all non-essential federal employees to work from home. Ethiopian Airlines was forced to gradually suspend all international flights, save for cargo flights. On 
20 March 2020, the Council of Ministers (CoM) decided to close the borders of the country save for those who agree to submit themselves for 14 days quarantine at their own expense.

Similarly, the states and some local governments put restrictions on public movements. For instance, Bahr Dar, the capital of Amhara state, imposed a two-week lockdown, starting from 31 March 2020. Several cities in Oromia, such as Adama and Assela, also suspended all public transportation.

The Tigray state was the first and the only state to invoke a state power to impose a state of emergency as per Article 93 of the Constitution. It declared an SoE with the objective of containing the virus. The state suspended public movements to and from rural areas within the state and ordered the closure of coffee houses, cafeterias, and other similar establishments for the duration of the SoE (Addis Standard 2020). It also required anyone entering the state to be tested. The Tigray SoE was followed five months later by a federal SoE, which was declared on 8 April 2020. ${ }^{3}$ The federal SoE imposed several restrictions and obligations. ${ }^{4}$ It ordered the closure of the borders of the country except for Ethiopian citizens. It required everyone to wear masks in public spaces, banned gatherings of more than four people and forbade shaking hands. It also required buses, trains, and other vehicles to use only half their capacity to transport people and for passengers to pay double the normal fee. Schools, clubs, bars, theatres, and cinemas were closed. Cafeterias, restaurants, and hotels were allowed to provide limited services. Sports and games involving more than two people were banned.

The SoE expired in August 2020, and many of the restrictions have been eased, at least in practice, despite the fact that the virus is still spreading at a growing rate. Ethiopian Airlines has resumed flights, and there is evident laxation in public movements within Addis Ababa despite the city being the epicenter of the virus.

Initially, there were problems in terms of coordinating the measures that the state and the federal government took to contain the spread of the virus. This was mainly due to the absence of formally established intergovernmental relations (IGR) fora in Ethiopia. Indeed, federal agencies had informal and ad hoc communication with their counterparts at state level on common issues. In the absence of formal IGR fora, it is these informal communication channels which are now being used for coordinating the effort to contain the virus. In this regard, the $\mathrm{MoH}$ is playing the principal role by liaising with states bureaus of health which, in turn, liaise with local offices of health. Information regarding testing and infection rates is sent by state bureaus of health to the $\mathrm{MoH}$ which produces a national report and makes it public every afternoon. As mentioned, the NECC, which is active under the NDRMC coordinates the humanitarian responses that are linked to the COVID-19 outbreak.

\subsubsection{Measures taken to ease adverse socio-economic impacts of COVID-19}

Ethiopia has been registering double-digit economic growth beginning from the early 2000s showing great progress in terms of poverty reduction. All that has been achieved in this regard is now threatened due to the emergence of COVID-19 which is not only undoing these achievements but also creating new economic and social challenges. 
The Federal Job Creation Commission report shows that 330,000 jobs have been lost thus far due to COVID-19 (see Ethiopian Reporter 2020; Bundervoet, Abebe and Wieser 2020). Likewise, a survey that the World Bank conducted in two rounds on the impact of COVID-19 on 550 business firms in Addis Ababa shows that 41 percent of them completely ceased operation even though this number decreased to 29 percent in the second round of the survey (Dione 2020). Up to 40 percent of the firms reported zero earning mainly due to up to 80 percent drop in demand for goods and services these firms provide (Dione 2020). A UN Ethiopia report indicates that, by causing up to a 4 percent drop in the country's GDP, COVID-19 will increase the number of those who live under the national income poverty line - currently 10 million - by 2.2 million (UN Ethiopia 2020). A survey by the World Bank shows that 45 percent and 55 percent of urban and rural households, respectively, have suffered income loses due to COVID-19 (Dabalen and Paci 2020). The government has reduced its own estimate of the country's economic growth for 2020, from 9 to 5.2 percent. Moreover, the virus emerged close to the main rainy season of the country which is gravely affecting the agriculture sector, the backbone of the country's economy and food security. The situation is worsened by the occurrence of a major locus infestation in six of the nine states (Tigray, Amhara, Somali, Afar, Oromia, and SNNP). Food inflation is thus hovering around 30 percent (WFP 2020).

The federal government is playing the most dominant role in terms of dealing with the adverse economic and social consequences of COVID-19. It has taken various measures aimed at alleviating the adverse economic impacts of COVID-19, including tax exemption on imported materials and equipment that can be used in containing the spread of the virus. It also gave tax exemptions to affected companies as well as cancelations of interest and penalties for unpaid taxes which were due between 2015 and 2018. Moreover, it introduced price controls on basic commodities. The National Bank also injected ETB 15 billion (USD 450 million) liquidity to private banks so that they could provide grace periods or 'debt relief and additional loans to their customers in need' (Samuel 2020). Employers are banned from dismissing their employees except in accordance with a protocol issued by the Ministry of Social Affairs. States and local governments are also introducing tax exemptions to small traders and businesses.

The full economic and social impacts of the virus are yet to be seen. It is evident though that the measures, such as tax exemptions and debt relief, which are being introduced by the federal and state governments, are likely to lead to a reduced public revenue which will directly impact the capacity of the federal, state, and local governments to provide basic services to the public.

\subsection{COVID-19 and its impacts on the Ethiopian federal system}

The federal system has indeed allowed each level of government to take steps that it deemed appropriate to contain the spread of the virus without waiting for instruction from the central government. A good example in this respect is the decision of the Tigray state to declare an SoE and implement various measures to restrict the spread of the virus. The various responses of the other states and cities also show how the federal system has allowed some degree of flexibility to authorities at different levels in terms of responding to the virus. Yet, the emergence of the virus has also exposed some serious flaws in the design of the Ethiopian federal system. 
First, as mentioned, formally established IGR fora are non-existent in the country. In the main, state and federal agencies interact with each other on ad hoc basis (Wakjira 2017). The absence of a properly institutionalized IGR system had thus made the responses of the two levels of government to the spread of the virus unsystematic and uncoordinated despite some improvement in this regard. For instance, initially, the report of the $\mathrm{MoH}$ on the number of infected people did not include reports from some states, most notably from the Tigray state which declared its report using its own media.

Second, according to many analysts, the emergence of COVID-19 has exposed a flaw in the constitutional adjudication system of the country. In Ethiopia, the HoF, the upper house of Parliament, is charged with resolving constitutional disputes, assisted in this respect by the Council of Constitutional Inquiry which is composed of judges and other legal experts (Art. 62(1) and 82-84, Ethiopian Constitution 1995). The HoF is a political organ which is composed on a partisan basis. In the past, various scholars had criticized this system of constitutional umpiring as unworkable. However, the framers of the constitution maintained that given the fact that the constitution is a political document, as much as it is a legal document, its interpretation could not be entrusted with unelected judges.

The COVID-19 pandemic therefore highlighted two major constitutional issues notably the flaw in the constitutional adjudication system of the country and the need for an independent constitutional umpire. The first issue has to do with the postponement of the sixth national elections. The national elections that were supposed to be held in May 2020 were postponed to August 2020 due to breakdown of law and order in different parts of country. As was mentioned in the introduction, the country came out of three years of public protest after the rise to power of Abiy Ahmed in April 2018, and the breakdown of law and order continued in different parts of the country months after the protests ceased. After the first case of COVID-19 was confirmed in Ethiopia, the National Elections Board of Ethiopia (NEBE) determined that it would be unable to administer the elections in August 2020. This presented a dilemma since the term of the sitting Parliament and state councils were set to expire on 10 October 2020. The Constitution provides barely any guidance on how the country would be governed after the expiry of the term of the current parliament and in the event of such a postponement of elections. Major opposition parties, including the TPLF, the Oromo Federalist Congress (OFC), and the Ethiopian Democratic Party (EDP), maintained that the current government will have no constitutional basis to continue governing the country after 10 October and that there was a need to politically settle the issue of how the country is to be governed until the next elections are held. The government ignored this call and asked the HoF to settle this issue by using its power of constitutional interpretation.

The HoF, based on the advice of the Council of Constitutional Inquiry, determined that the sixth general elections could be postponed until, with the advice of the $\mathrm{MoH}$ and the NEBE, the HPR determines that it was safe to hold elections. Put differently, the HoF authorized the government to unilaterally decide if and when to hold the next elections and, in the meantime, to exercise undiminished political powers (Council of Constitutional Inquiry 2020). This decision put the government on a collision course with the opposition and caused much unrest.

The second constitutional issue has to do with the decision of the Tigray state to hold its own elections. The TPLF insisted on the elections being held before the 


\section{2}

Zemelak Ayitenew Ayele

expiry of the term of Parliament and state councils. After the NEBE rejected its request to administer a state-wide election in Tigray, the Tigray state adopted its own election law and established a state election board. Tigray state's resolution in this respect was constitutionally questionable. This is because all matters relating to elections lie within the competences of the federal government and that all elections are administered by the NEBE (Art. 51(15) and 102, Constitution Act 1995). The failure to resolve this deadlock through the normal process of constitutional adjudication created a constitutional crisis. The already strained relations between Tigray state and the federal government deteriorated rapidly precipitating an intensive armed confrontation. Following Tigray's decision to defy the HoF's and the federal government's formal overture and press ahead with state elections, in November 2020, federal forces were dispatched to enforce what the Prime Minister called the 'rule of law.' At the time of writing, federal forces had established control of the state capital.

\subsection{Conclusion}

The COVID-19 pandemic has already posed immense political, economic, and social challenges in Ethiopia. It has stalled a political process that was hoped to transform the country into a democratic state. It has undone progress made in terms of poverty reduction. It has also shown some major flaws in the design of the Ethiopian federal system. Yet not everything is doom and gloom. There is unprecedented debate on traditional and social media on the design and future of the country's federalism among academics and the people at large. This indicates the growing awareness of, and public interest in, matters relating to the country's federal system.

\section{Notes}

1 The original nine states were Tigray, Afar, Amhara, Oromia, Somali, Hareri, Gambella, Benishangul-Gumuz, and Southern Nations and Nationalities and Peoples (SNNP). The tenth state, the Sidama was created in June 2020.

2 In its establishing proclamation, this authority was called 'Ethiopian Food Medicine and Healthcare Administration and Control Authority. Food, Medicine and Health Care Administration and Control Proclamation 661 (2009) and Food and Medicine Administration Proclamations 661(2009) and 1112(2009).

3 State of Emergency Proclamation Enacted to Counter and Control the Spread of the COVID-19 and Mitigate Its Impact Proclamation No 3 (2020).

4 A Regulation issued by the Council of Ministers to implement the State of Emergency Proclamation 3(2020).

\section{Bibliography}

Addis Standard, 2020. Tigray Region Declares State of Emergency to Prevent Spread of \#COVID19 [online]. Addis Standard, 26 March. Available from: https://addisstandard. com/news-alert-tigray-region-declares-state-of-emergency-to-prevent-spread-of-covid19/ [Accessed 12 March 2020].

Ayele, Z., 2014. Local Government in Ethiopia: Advancing Development and Accommodating Ethnic Minorities, Baden-Baden-Nomos Verlagsges.

Ayele, Z. and Fessha, Y., 2012. The Place and Status of Local Government in Federal States: The Case of Ethiopia. African Today, 58 (4), 89-109. 
Bundervoet, T., Abebe, G. and Wieser, C., 2020. Monitoring COVID-19 Impacts on Firms in Ethiopia: Results from a High-Frequency Phone Survey. World Bank Group, 6 June. Available from: http://documents1.worldbank.org/curated/en/939631591634604256/pdf/Resultsfrom-a-High-Frequency-Phone-Survey-of-Firms.pdf [Accessed 12 March 2021].

Constitution of the Federal Democratic Republic of Ethiopia, 21 August 1995. Chapter 6, Article 51(15), Article 51(18), Article 62(1), Articles 82-84, Article 93, Article 93(1)(b), Article 102.

Dabalen, A. and Paci, P., 2020. How Severe Will the Poverty Impacts of COVID-19 be in Africa? World Bank, 5 August. Available from: https://blogs.worldbank.org/africacan/howsevere-will-poverty-impacts-covid-19-be-africa [Accessed 07 August 2020].

Dione, O., 2020. Tackling the Impacts of COVID-19 Is Imperative to Ethiopia's Journey to Prosperity [online]. World Bank, 29 October. Available from: https://blogs.worldbank.org/ africacan/tackling-impacts-covid-19-imperative-ethiopias-journey-prosperity [Accessed 14 December 2020].

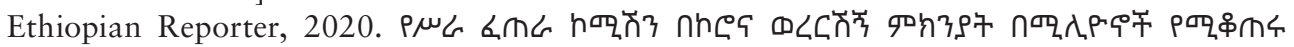

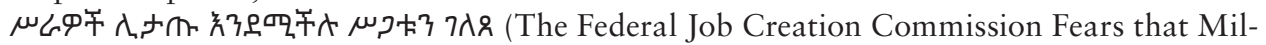
lions of Jobs Could Be Lost Due to COVID-19). Ethiopian Reporter, 26 July. Available from: https://www.ethiopianreporter.com/article/19417 [Accessed 12 March 2021].

FDRE, 2013. Ethiopian Public Health Institute Establishment Regulation 301, Article 6.

FDRE Council of Constitutional Inquiry, May 2020. Recommendations on Constitutional Issues that the House of Peoples Representatives Sent to the CCI in Relation to the Postpone-

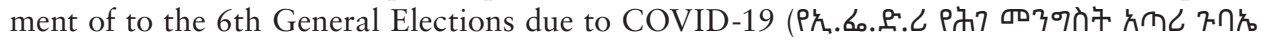

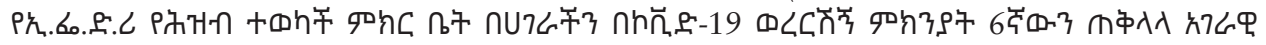

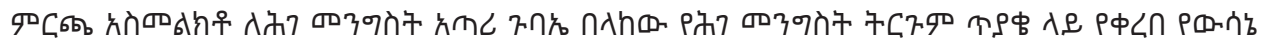

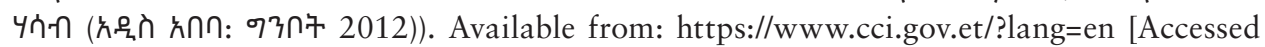
12 March 2021].

Fiseha, A., 2007. Federalism and the Accommodation of Diversity in Ethiopia: A Comparative Study. Nijmegen: Wolf Legal Publishers.

Fiseha, A. and Ayele, Z., 2017. Concurrent Powers in the Ethiopian Federal System. In: Steytler, N., eds. Concurrent Powers in Federal Systems: Meaning Making and Managing. Leiden: Koninklijke Brill NW, 241-260.

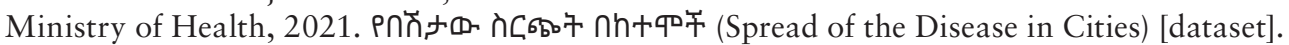
Federal Democratic Republic Ethiopia. Available from: https://www.covid19.et/covid-19/ [Accessed 14 December 2020].

Proclamation 661, Federal Democratic Republic of Ethiopia 2009, Article 4(15), Article $52(2)(\mathrm{c})$.

Proclamation 1097, Federal Democratic Republic of Ethiopia 2018, Article 27.

Proclamation 1112, Federal Democratic Republic of Ethiopia 2019, Article 72(2).

Samuel, G., 2020. State Avails Stimulus Package to Rescue Banking Industry: The Gov't Avails 15 Billion ETB to Banks through the National Bank of Ethiopia. Addis Fortune, 28 March. Available from: https://addisfortune.news/state-avails-stimulus-package-to-rescue-bankingindustry/ [Accessed 7 September 2020].

UN Ethiopia, 2020. Socio-Economic Impact of COVID-19 in Ethiopia. Addis Ababa: UN Ethiopia. Available from: https://reliefweb.int/sites/reliefweb.int/files/resources/ UN\%2520Socio-Economic\%2520Impact\%2520Assessment\%2520-\%2520FINAL\%2520DR AFT\%2520\%2520-\%252014May20.pdf [Accessed 29 July 2020].

Wakjira, K., 2017. Institutionalization of IGR in the Ethiopian Federation: Towards Cooperative or Coercive Federalism? Ethiopian Journal of Federal Studies, 4 (2), 121-160.

WFP, World Food Programme, May 2020. WFP Ethiopia Market Watch: Food Security Analysis. Available from: https://reliefweb.int/sites/reliefweb.int/files/resources/WFP\%20Ethiopia\%20Market\%20Watch\%20-\%20May\%202020.pdf [Accessed 8 September 2020]. 